\title{
Changes in the timing of departure and arrival of Irish migrant waterbirds
}

Alison Donnelly, Heather Geyer, Rong Yu

There have been many recent reports across Europe and North America of a change in the timing of arrival and departure of a range of migrant bird species to their breeding grounds. These studies have focused primarily on passerine birds and climate warming has been found to be one of the main drivers of earlier arrival and departure in spring. In Ireland, rising spring temperature has been shown to result in the earlier arrival of subSaharan passerine species and the early departure of the Whooper Swan. In order to investigate changes in spring arrival and departure dates of waterbirds to Ireland we extracted latest dates as an indicator of the timing of departure of winter visitors (24 species) and earliest dates as an indicator of the timing of arrival of spring/summer migrants (2 species) from BirdWatch Ireland's East Coast Bird reports (1980-2003). Three of the winter visitors showed evidence of later departure and 1 of earlier departure whereas one of the spring/summer visitors showed evidence of earlier arrival. In order to determine any influence of local temperature on these trends we analysed data from two synoptic weather stations within the study area and found that spring (average February, March and April) air temperature significantly $(P<0.05)$ increased at a rate of $0.030 \mathrm{C}$ per year which was strongly correlated with changes in latest and earliest records. We also tested the sensitivity of bird departure/arrival to temperature and found that Northern Pintail would leave 10 days earlier in response to a $1^{\circ} \mathrm{C}$ increase in spring temperature. In addition, we investigated the impact of a large-scale circulation pattern, the North Atlantic Oscillation (NAO), on the timing of arrival and departure which correlated with both advances and delays in departure and arrival. We conclude that the impact of climate change on earliest and latest records of these birds is, as expected, species specific and that local temperature had less of an influence than large-scale circulation patterns. 


\section{Changes in the timing of departure and arrival of Irish migrant waterbirds}

2 Alison Donnelly ${ }^{1^{*}}$ Heather Geyer ${ }^{2}$ and Rong $\mathrm{Yu}^{3}$

$3{ }^{1}$ Department of Geography, University of Wisconsin-Milwaukee, WI 53201, USA

$4 \quad{ }^{2}$ Centre for the Environment, Trinity College Dublin, Dublin 2, Ireland

$5{ }^{3}$ Fulton Schools of Engineering, Arizona State University, Mesa, AZ 85212, USA

$6 \quad{ }^{*}$ Corresponding author: Phone: (1) 414-334-1510

Email: alison.c.donnelly@gmail.com 
9 Despite the vast amount of research being carried out on climate change, there remains a

10 degree of uncertainty as to the nature of any future impacts on ecosystems (IPCC 2013). This

11 uncertainty stems from the range of complexities associated with climate change coupled with

12 the fact that changes are expected to be region-specific (Alcamo et al., 2007). While the exact

13 nature of future climate remains unclear, it is now understood that the changes that have

14 occurred are outside the realm of natural variability (Hurrell and Trenberth, 2010; IPCC 2007 \&

15 2013). Understanding the environmental implications which have occurred to date as a result of

16 this anthropogenically forced climate change will provide better awareness of what future

17 impacts to expect. Furthermore, the influence of large-scale oscillations in climate, such as the

18 North Atlantic Oscillation (NAO) which also impact spring temperature should also be considered

19 when examining the influence of climate on wildlife.

20 The North Atlantic Oscillation is a large-scale fluctuation in atmospheric mass between high and 21 low pressure cells which are centred near the Azores and Iceland (Cook, Smith and Mann, 22 2005). It is considered the most significant atmospheric oscillation in the North Atlantic region 23 (Stenseth et al., 2003; Goodkin et al., 2008) with its climatic effects stretching east to the United 24 States, north to Greenland, south to Africa and west into Asia. Although active throughout the 25 whole of the year, its effects are strongest from November to April (Visbeck et al., 2001; Goodkin 26 et al., 2008; Stenseth et al., 2003). A positive NAO is associated with warmer winter 27 temperatures along with stronger westerly winds across the North Atlantic. A negative NAO is 28 associated with cooler winter temperatures (Hurrell, 1995; Cook, Smith and Mann, 2005). In 29 addition to interannual variability, multidecadal patterns of the NAO have also been revealed. 30 Recent research suggests that these patterns have become increasingly pronounced, 31 particularly over the last half of the $20^{\text {th }}$ century (Hurrell and Van Loon, 1997; Goodkin et al., 32 2008) and suggest that anthropogenic forcing may be responsible for the intensified nature of 33 the more recent NAO phases (Goodkin et al., 2008). Increasing global temperatures coupled 34 with increasingly exaggerated NAO phases makes predicting the impact of climate change on ecosystems extremely challenging.

As a means of quantifying the impact of climate change on wildlife, much research has focused on shifts in phenology. These recurring annual events, including bird migration, are often strongly correlated with temperature (Cotton, 2003; Jonzén et al., 2006; Sparks et al., 2005; Miller-Rushing et al., 2008; Donnelly et al., 2009). Migration has evolved in a number of species as an adaptive strategy to seasonal changes in the abundance of essential resources (Berthold 
42 must cope with a variety of changes including shifts in food availability, weather and social 43 behaviour (O'Reilly and Wingfield, 1995).

44 While migration has enabled birds to utilize typically unsuitable habitats, it also increases their 45 vulnerability to climatic variability. Weather influences their foraging behaviour, metabolic rate, 46 and breeding success (Crick, 2004). Since climate change is having a significant impact on both 47 the structure and the functioning of ecosystems, it is highly likely that some migratory waterbirds 48 may be affected, by for example, changes in the timing of resource availability at breeding 49 grounds. In the past century, Europe has experienced an increase in annual average air 50 temperature of approximately $0.8{ }^{\circ} \mathrm{C}$ (IPCC, 2013). This increase has been linked to the earlier 51 nesting dates as well as the earlier arrival and departure of some migrant bird species (Cotton, 52 2003; Jonzén et al., 2006; Crick, 2004; Donnelly et al., 2009; Stirnemann et al. 2011). Whereas, 53 an advance in the timing of first arrival dates has often been reported as an indicator of warming 54 care must be exercised not to interpret or extrapolate these trends to the population level 55 (Sparks et al., 2001). The authors argue that data on the complete migration distribution may 56 often not be available therefore reporting a change in one tail of a distribution is nonetheless 57 valid, if not ideal.

58 A study focusing on the timing of spring migrant passerine birds to Ireland observed a trend of 59 earlier arrival in long-distance migrants during the spring, which was found to be directly related 60 to increasing air temperatures (Donnelly et al., 2009). In addition, a winter visitor, the Whooper 61 Swan has also been reported to leave earlier in spring in response to rising spring temperature 62 (Stirnemann et al. 2011). Research conducted by Rubolini et al., (2007) suggests that the 63 response of migratory birds to changing climatic conditions is species specific. They recommend 64 that phylogenetic history be taken into account when comparing those responses as closely 65 related species are more likely to show similarities. The study also indicated that spatial 66 variability and migratory patterns influence response to warming, with short-distance migrants 67 advancing their spring arrival dates more so than long-distance migrants although other studies 68 albeit using different species and geographical location, suggest otherwise, emphasizing the 69 complex nature of migratory patterns and phenotypic plasticity (Rubolini et al., 2007; Jonzén et 70 al., 2006).

71 As Ireland lies directly within the East Atlantic Flyway and remains an important stopover point 72 and final destination for migratory bird species, understanding the impact of climate change on 73 bird migration is important, especially in relation to the European Union's Habitat and Birds 74 Directives (UNEP and CMS, 2011). Recent studies have reported an advance in the timing of 75 both leafing of trees (Donnelly et al., 2006) and arrival of spring migrant birds (Donnelly et al., 
76 2009) in response to warming thus demonstrating a detectable impact of climate change on Irish

77 wildlife. Future estimates predict that annual mean temperature in Europe will likely surpass the

78 global mean (IPCC, 2013). These unprecedented increases in temperature will continue to have

79 knock-on effects throughout Irish ecosystems.

80 In this study, annual bird reports covering the east coast region of Ireland were utilized to create

81 a unique dataset of latest recorded dates in spring for winter visiting waterbirds and earliest

82 dates for spring/summer visitors as indicators for departure (winter visitors) and arrival

83 (spring/summer arrivals). In addition, local spring air temperature and trends in the North Atlantic

84 Oscillation Index for the time period of interest were also obtained. Together these datasets were

85 used to (i) investigate if changes in the timing of spring departure/arrival of migrant waterbirds

86 occurred over the time period (1980-2003) and (ii) determine whether or not local temperature

87 and/or large-scale short-term circulation patterns were driving any observed phenological trend. 
In order to examine arrival and departure dates of migrant waterbirds to Ireland we examined records from the Irish East Coast Bird Reports (BirdWatch Ireland) over a 24-year period (19802003). These reports were compiled from records submitted by known birdwatchers to BirdWatch Ireland of sightings and counts of all bird species within part of the East coast region (Figure 1). We extracted earliest reporter dates in spring as an indicator of the timing of arrival of spring/summer migrants and latest reported dates as an indicator of the timing of departure of winter visitors.

The Irish East Coast Bird Reports (Cooney et al. 1980-1991; Cooney and Madden 1992-1995; Madden and Cooney, 1996; Madden, 1997; Madden and Cooney, 1999; Coombes and Murphy, 2000-2003) have been compiled and published by BirdWatch Ireland (formerly known as the Irish Wildbird Conservancy) from 1980 to 2003 with the exception of 1997 when funding was unavailable. A full set of the reports is available from the library at BirdWatch Ireland (www.birdwatchireland.ie) and at two other libraries that we know of; Trinity College Dublin (www.tcd.ie), Ireland and University College Dublin (www.ucd.ie), Ireland. The approximate length of the coastal area covered by the reports is $200 \mathrm{Km}$ and spans four counties; Louth, Meath, Dublin and Wicklow (Figure 1). The reports were edited by between 1-5 professionals working for BirdWatch Ireland who validated each record prior to publication. Contributors to the reports included both professional and amateur birdwatchers and ranged in number from 43 to 108 with an average of 76 contributors per year. The list of contributors is provided in each report and many of the contributors' names are consistent over the time period of the reports. It was not possible to accurately ascertain the frequency at which observations were made as this

111 level of detail was not provided. However, in an attempt to address this question, we contacted

112 BirdWatch Ireland and they informed us that each observer made observations at least weekly.

113 The focus of this study was specifically on early and late dates of migrant birds as an indication

114 of possible changes in the timing of spring arrival and departure but we were nonetheless 115 cognisant of using records of one individual bird as representing the population as a whole. 116 Therefore, when the recorded number of individuals in a particular species was consistently high

117 (e.g. Red Knot) over the time period, records of <8-10 individuals were not included in the 118 statistical analysis whereas when numbers were typically low (e.g. Long-tailed Duck) records of 119 2-3 individuals were included. Data that were excluded from analysis as numbers were 120 considered misrepresentative were as follows; Red-throated Diver (2 individuals reported on 121 DOY 210 in 1992), Great Northern Diver (singles up to DOY 189 in 1984), Greylag Goose (1 
122 individual on DOY 143 in 1981), Brent Goose (2 individuals on DOY 161 in 1984 and 1 on DOY

123175 in 1990), Eurasian Wigeon (1 on DOY 173 in 1981, 1 on DOY 158 in 1982 and 2 on DOY

124167 in 1984), Eurasian Teal (1 on DOY 197 in 1991), Common Pochard (2 on unspecified dates

125 in Jun., Jul. and Aug. 1981), Greater Scaup (1 on DOY 156 in 1985), Common Goldeneye (1 on

126 DOY 137 in 1987), Grey Plover (1 on DOY 146 in 1987) and Common Greenshank (1 on DOY

127165 in 1986). In addition, when records of a particular bird were available for each month of the

128 year making it impossible to extract latest or earliest dates, data for these years were excluded.

129 For example, in 1987 Sanderling were recorded in every month of the year and so data for this

130 year were omitted. Similarly, data for Common Scoter (1985), Grey Plover (1989), Purple

131 Sandpiper (1989), Black-tailed Godwit (1986-1988), Common Redshank (1991), Common

132 Greenshank (1991) and Ruddy Turnstone (1986-1989) were also omitted from the analysis. The

133 average number of birds (recorded on the day observations were being made) per year is

134 reported in Table 1 together with the standard deviation to present the large inter-species and

135 interannual variation in numbers.

136 Species considered for this study were categorized as follows; divers (aquatic diving bird e.g.

137 Red-throated Diver, Sandwich Tern), waterfowl (ducks and geese e.g. Wigeon) and waders

138 (forage primarily along the seashore e.g. Grey Plover) for which earliest and latest dates were

139 published in the reports (Table 1). Since there were many instances of missing values only

140 species with a minimum of 15 years of records were included as this was considered sufficient

141 for robust statistical analysis (following Rubolini et al., 2007 and Donnelly et al., 2009). All

142 earliest and latest dates were converted to day of year (DOY). Statistical analyses were

143 performed on 26 species of migratory waterbirds out of a total of 40 species considered. The

144 following 14 species did not meet the required criteria, Garganey Anas querquedula Eider

145 Somateria mollissima; Shoveler Anas clypeata; Goldeneye Bucephala clangula; Goosander

146 Mergus merganser; Velvet Scoter Mellanitta fusca; Ruddy Duck Oxyura jamaicensis; Spotted

147 Redshank Tringa erythropus; Green Sandpiper Tringa ochropus; Iceland gull Larus glaucoides;

148 Arctic tern Sterna paradisaea; Roseate Tern Sterna dougallii; Little Tern Sterna albifrons; Puffin

149 Fratercula arctica.

150 Climate data

151 The climate data used in this study were supplied by the Irish meteorological service 152 (http://www.met.ie/climate/climate-data-information.asp), Met Éireann. In order to examine the 153 impact of local temperature on the timing of earliest and latest dates of migrant waterbirds, the 154 average monthly air temperatures for the study area were acquired using data from the service's 155 two synoptic weather stations located at Dublin airport (53²5'40" N 6¹4'27" W) and Casement 
156 aerodrome $\left(53^{\circ} 18^{\prime} 20^{\prime \prime} \mathrm{N}, 6^{\circ} 26^{\prime} 20^{\prime \prime} \mathrm{W}\right)$ (Figure 1). The furthest coastal point from the nearest

157 weather station was approximately $50 \mathrm{Km}$. Since the monthly average temperature difference

158 between the sites was consistently less than $0.5^{\circ} \mathrm{C}$ an average for the study area was calculated

159 and used in all subsequent analyses. Daily maximum and minimum temperatures were

160 averaged for the months of January, February, March and April. In addition, average

161 temperatures were also calculated from February to April, representing 'average spring

162 temperatures'.

163 Furthermore, the influence of large-scale circulation patterns on the timing of arrival was 164 investigated. Data for the winter (December-February) North Atlantic Oscillation (NAO) were 165 obtained from the Climate Research Unit websites at East Anglia University, Norwich, UK for 166 years 1980 to 2000 (http://www.cru.uea.ac.uk/cru/data/nao.htm/) and for 2001 to 2003 167 (http://www.cru.uea.ac.uk/ timo/datapages/naoi.htm).

168 Statistical analysis

169 The latest date (Day of Year) recorded in spring of 24 winter species and the earliest date of two 170 spring/summer species (Table 1 \& Figure 2) of migrant waterbird was first plotted against year 171 (1980-2003) to determine any temporal pattern in the time series' e.g. Figure 2. Trends in the 172 timing of earliest and latest dates (DOY) were analyzed independently for each species using 173 the MULTMK/PARTMK program for the computation of univariate Mann-Kendall tests (Libiseller 174 and Grimvall, 2002). The Mann-Kendall test is a robust method for examining monotonic trends 175 in a time series, has the advantage of being able to deal with missing values (Wahlin and 176 Grimvall 2010) and has been previously used in similar studies (Richardson et al. 2006; 177 Donnelly et al. 2009).

178 Linear regression was used to determine the trend in average spring temperature and to 179 examine the relationship between departure/arrival and the climatic variables, similar to Miller180 Rushing et al., (2008). We first tested for temporal autocorrelation in departure/arrival and 181 climate parameters (including NAOI) using the Box-Ljung test and found only 3 instances of 182 significant lag-1 autocorrelation (Pochard (correlation for lag-1 $=0.389 \pm 0.019$, Box-Ljung 183 statistic $=4.181, P=0.04$ ), Knot (correlation for lag-1 $=0.403 \pm 0.0195$, Box-Ljung statistic $=$ $1844.252, P=0.04$ ) and Tern (correlation for lag-1 $=0.410 \pm 0.019$, Box-Ljung statistic $=4.668, P=$ 185 0.03). We detrended these data by subtracting the value in year $(i)$ from that in year $(i-1)$ and 186 repeated the multiple regression analysis. Since neither the original data nor the detrended data 187 showed significant correlations with temperature variables and NAOI we used the original data

188 for simplicity and consistency (following Balbontín et al., 2009). All statistical tests (apart from the 189 Mann-Kendall test) were carried out using IBM SPSS version 20.0. 


\section{Temperature trends}

192 As expected, monthly average spring (February to April) air temperatures, averaged acrosstwo 193 meteorological stations, Dublin Airport and Casement Aerodrome, within the study area for the 194 period 1980 to 2003 showed a statistically significant $\left(R^{2}=0.193 ; P=0.0541\right)$ increasing trend $195\left(0.04^{\circ} \mathrm{C}\right.$ per year) towards warmer temperatures (Figure 2$)$.

\section{Temporal pattern in departure and arrival of migrant waterbird species}

197 The number of individuals recorded on the latest (winter visitors) and earliest (spring visitors) 198 dates in spring is presented in Table 1 (note: these data do not represent peak counts but rather 199 the numbers present on the particular date). The largest numbers reported were waders such as

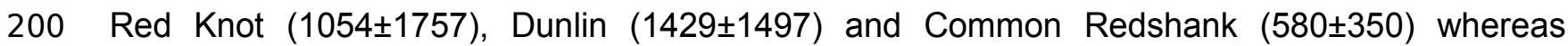

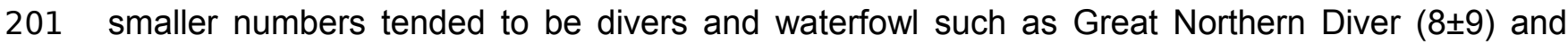
202 Long-tailed Duck $(7 \pm 10)$ although one species of wader, Jack Snipe was also reported in small

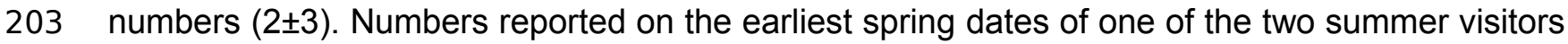
204 were large (Manx Shearwater 626 1801) whereas a similar result for the Sandwich Tern was $2052 \pm 2$. These datareflect variation between species in numbers of both early and late recordings.

206 One waterfowl and two waders (Northern Pintail $(P=0.0374)$, Purple Sandpiper $(P=0.0156)$ and 207 Dunlin (Figure 3a $P=0.0118)$ ) revealed a statistically significant later trend in the latest recorded 208 date in spring over the time period examined (Table 1). Even though the majority (16 out of 24) 209 of species showed a tendency to remain in Ireland longer as indicated by positive values 210 resulting from the Mann-Kendall test most were not statistically significant. . The latest recorded 211 dates of one wader (the Common Greenshank $(P=0.0200)$ out of the eight species exhibiting 212 negative M-K trends was statistically significantly earlier. The earliest observed dates of one of 213 the two spring/summer visiting waterbirds (Sandwich Tern (Figure 3b $P=0.0009$ )) became earlier 214 over time.

215 Overall the earliest date by which the wintering birds left the east coast of Ireland was DOY 19 216 (19 Jan.) whereas the latest date was DOY 212 (31 Jul.), reflecting the wide range of latest 217 dates recorded between 1980 and 2003 (Table 1). The earliest dates the two spring/summer 218 migrants arrived was DOY 71 (12 March) and the latest was DOY 163 (12 June) which reflects a 219 much narrower time period but there were only 2 species of waterbird examined in this category, 220 the Manx Shearwater and the Sandwich Tern. 
221

222 The influence of local spring temperature on latest (winter visitors) and earliest (spring/summer

223 visitors) bird records revealed both positive and negative trends depending on the species in

224 question (Table 2). Of the months considered, temperature in March showed the strongest

225 correlations. The timing of departure (latest records) of only 1 of the twenty-four winter visitors

226 examined showed positive correlations with March temperature (Whooper Swan $\left(12 \mathrm{~d}{ }^{\circ} \mathrm{C}^{-1}\right.$;

$\left.227 R^{2}=0.182 ; P=0.042\right)$ ). This suggests that when March temperature was relatively warm this

228 species remained in Ireland later into the season. However, some species showed the opposite

229 trend. For example, the timing of departure of both Red-throated Diver $\left(-6 \mathrm{~d}^{\circ} \mathrm{C}^{-1} ; R^{2}=0.173\right.$;

$230 P=0.054)$ and Northern Pintail $\left(-8 d^{\circ} C^{-1} ; R^{2}=0.378 ; P=0.019\right)$ became significantly earlier as

231 March temperature increased suggesting that these waterbirds leave Ireland earlier as March

232 temperature rises (Table 2). The earliest records observed of the spring/summer visitors also

233 became progressively earlier in the season as March temperature increased but this trend was

234 not statistically significant (Table 2).

235 Sensitivity to overall spring warming

236 The response of the timing of departure and arrival to a $1^{\circ} \mathrm{C}$ increase in average spring 237 temperature varied greatly between species (Table 2) indicating that some birds showed greater 238 sensitivity to changing temperature than others. The Northern Pintail $\left(-10 \mathrm{~d}^{\circ} \mathrm{C}^{-1} ; R^{2}=0.392\right.$; $239 P=0.017$; Figure 4) significantly advanced their timing of departure in response to $1^{\circ} \mathrm{C}$ increase 240 in average spring temperature whereas none of the positive trends were statistically significant.

241 The summer visitors showed only weak correlations with temperature variables.

242

Influence of large-scale circulation patterns on bird migration

243 The timing of departure (latest spring record) of the Red-throated Diver (-9d index unit ${ }^{-1}$; $244 R^{2}=0.386 ; P=0.002$; Figure 5 ), was found to be statistically negatively correlated with the winter 245 (December-February) NAOI (Table 2). This negative correlation suggests that during a positive 246 NAO phase the timing of departure was earlier in the year (Figure 5). Two (Greater Scaup (18d 247 index unit $\left.{ }^{-1} ; R^{2}=0.386 ; P=0.002\right)$ and Common Goldeneye (23d index unit $\left.{ }^{-1} ; R^{2}=0.386 ; P=0.002\right)$ )

248 of the 10 species exhibiting positive correlations were statistically significant suggesting that 249 250 departure was later when the NAOI was positive (Table 2). Both summer visitors showed only weak correlations with the NAO index. 
252 Our results indicate a change in the timing of the latest and earliest recorded dates in spring of a 253 number (5 out of 26) of migrant waterbirds to the east coast region of Ireland over a 24-year 254 period (1980-2003). We proposed that the latest recorded date in spring of winter visitors may 255 be used as an indicator of the timing of last departure whereas the earliest recorded date in 256 spring of spring/summer migrants may be used as an indicator of the timing of first arrival. Even 257 though the records reported in BirdWatch Ireland's East Coast Bird Reports were not specifically 258 collected for the purpose of determining latest departure or earliest arrival dates of migrant birds 259 given the systematic and rigorous manner used to generate these data we are confident that the 260 trends reported here are real. However, more detailed records, such as daily counts, would 261 undoubtedly give a more accurate account of migration at a population level, but in the absence 262 of such data these reports yielded some interesting trends. Furthermore, keeping in mind 263 Aristotle's phrase 'one swallow does not make a summer' we attempted to avoid incorporating 264 outliers as representative of wider behavioural trends, where appropriate. For example, we 265 excluded reports of one or two birds very late in the season when numbers of the species in 266 question were normally reported in tens or hundreds. In addition, it was not always possible to 267 extract the latest record in a particular season as sightings may have been reported for every 268 month of the year. In these cases data for the particular year were omitted. Instances of this 269 nature were infrequent but may be interesting to explore in future as it suggests that some winter 270 migrants may be beginning to remain in Ireland year-round and may, in future, become resident 271 providing environmental conditions and food supply were suitable.

272 Identifying, appropriate data sets by which to examine the influence of climate change on bird 273 migration patterns poses many challenges (Knudsen et al, 2009) and in the absence of long274 term dedicated monitoring networks we may seek alternative means by which to explore such 275 relationships (Donnelly et al., 2014). Some of the limitations of the data used in the current study 276 include the lack of population-level data and it would not be appropriate to extrapolate the 277 current trends to a broader geographic area or to a population level. Data representing the tails 278 of a distribution, such as last departure or first arrival, are limited in their usefulness for the 279 reasons just mentioned but nonetheless have been shown to be weakly representative of 280 population size and distribution (Sparks et al, 2001; Stirnemann et al., 2011). In addition, 281 sampling effort may influence early or late sightings and therefore may introduce bias into the 282 trends (Sparks, Huber and Tryjonowski, 2008). However, we found the number of contributors to 283 the reports to be fairly consistent over time with an average of 76 per year with many of the 284 names being repeated over the 24-year period which would certainly help reduce any such bias. 285 The timing of spring departure of all categories (diver (2), waterfowl (11) and wader (11)) of 
286 winter visiting waterbirds examined in this 24-year dataset revealed that the majority (16 out of 287 24) of species showed a tendency to remain in Ireland later in the season over the time period 288 examined but the trend varied between species. The fact that only very few of the trends were 289 statistically significant is more than likely due, at least in part, to the short length of the time 290 series. Reports of significant trends usually have 30 or more years' data (Cotton, 2003; Miller291 Rushing et al., 2008; Donnelly et al., 2009; Lehikoinen and Jaatinen 2011; Stirnemann et al. 292 2012). However, the records used here were restricted to the time period 1980-2003. The 293 reason(s) these birds may be staying around longer is unclear but (as mentioned above) may 294 result in some of these birds becoming resident in Ireland. Interestingly, the delayed trend was 295 not observed for all species as eight species, including two categories (waterfowl (3) and wader 296 (5)), showed a tendency to depart earlier. The earlier trend for Whooper Swan, although not 297 statistically significant, was in agreement with a previous study in which daily counts (1972298 2008) of this species revealed earlier spring departure from a wintering site in the southern part 299 of Ireland (Kilcolman Wildlfowl Refuge, Co. Cork) (Stirnemann et al. 2012). The early departure 300 was indirectly influenced by an increase in February temperature at the site which had a direct 301 impact on the food supply. Grass yield (food supply) was greatest in years when February 302 temperatures were warmer than average thus allowing birds to get in condition and depart early.

303 In addition, competition for resources in the wintering grounds also significantly influenced the 304 timing of departure (Stirnemann et al. 2012). The larger the population the earlier the departure. 305 It would be interesting to examine whether the birds remaining later in the season are also 306 arriving later in autumn to examine if there is a shift in the overall timing of arrival and departure 307 of these species.

308 A study carried out by Lehikoinen and Jaatinen (2011) over a 31-year period (1979-2009) 309 examined daily counts of autumn departure in northern Europe of a number of waterfowl 310 including 6 of the species examined in the current study. Even though the methods of data 311 collection were very different between the 2 studies some interesting observations could be 312 made. For example, the beginning of autumn departure from Finland was significantly delayed 313 for Eurasian Wigeon while the departure in spring for the same species in Ireland also tended to 314 be delayed $(P=0.0864)$. In other words, these waterfowl were found to be staying (in Finland) 315 later in autumn and leaving (from Ireland) later in spring. Greylag Goose, Pintain and Goldeneye 316 at both locations showed similar tendencies. These comparisons suggest a possible shift in the 317 timing of residence in European wintering grounds and highlight the need to examine the entire 318 annual migration of migrant birds rather than focusing on spring or autumn in isolation. However, 319 more detailed data would be required to confirm these patterns. 
320 The tendency towards early arrival of both (only the Sandwich Tern was statistically significant)

321 spring/summer migrants examined in this study was similar to that reported for a number of sub-

322 Saharan migrant visitors to the same region of Ireland (Donnelly et al. 2009). Nine (seven of

323 which were statistically significant) out of eleven passerine species examined revealed an

324 advance in the timing of arrival (1969-1999) which was strongly correlated with average March

325 temperature. Given the different habitats occupied by the passerines and waterbirds it is

326 nonetheless interesting that a similar pattern of earlier arrival was revealed. Furthermore, the

327 Manx Shearwater is a long-distance migrant wintering at sea in the South Atlantic whereas the

328 Sandwich Tern winters in southern Europe and Africa. Even though these birds travel very

329 different distances, with earliest observed sightings reported in different numbers $(626 \pm 1801$

330 (Manx Shearwater) vs $2 \pm 2$ (Sandwich Tern)) and on average arrive in Ireland more than a month

331 apart their earlier arrival tendency is of interest. It would be useful to examine trends of a range

332 of long- and short-distance species to determine if their arrival followed a similar pattern.

333 The departure of the winter visitors was influenced by rising spring temperature, especially in 334 March. Both negative (Red-throated Diver and Northern Pintail) and positive (Whooper Swan)

335 correlations were revealed. The majority of winter visiting birds showed positive correlations,

336 between the timing of departure and March temperature, although not always statistically

337 significant, was somewhat unexpected. The Whooper Swan tended to depart earlier over the

338 time period (1980-2003) and a previous study (Stirnemann et al. 2012) reported the earlier

339 departure to be negatively correlated with February temperature. However, in this study

340 departure was also negatively, but not statistically significantly, correlated with February

341 temperature but was positively (statistically significantly) correlated with March temperature. One

342 reason for this may be that March temperature, in reality, has little impact but just happened to

343 be correlated significantly. However, in contrast the Greylag Goose revealed a non-significant

344 trend towards delayed departure which was significantly correlated with March temperature.

345 When examining departure response to average spring temperature, some birds departed

346 earlier when spring temperature was warmer and most species showed a similar tendency.

347 Sensitivity to warming temperatures varied between species. $A 1^{\circ} \mathrm{C}$ increase in spring

348 temperature revealed, as expected, a range of responses from a delay of more than 10

349 days $/ 1^{\circ} \mathrm{C}$ for Northern Pintail to little or no response for other species such as the Greylag

350 Goose. These contrasting trends highlight the complexity of the relationship between bird

351 departure and temperature, the species specific nature of the relationship and the need to

352 explore a wider range of temperature drivers in order to explain observed trends.

353 A northward shift in the population centre of gravity of a number of European waterbirds, 354 including Goldeneye, in response to rising winter temperature has resulted in a decrease in 
355 population numbers in Ireland and an increase further north in Scandinavia (Lehikoinen et al.

356 2013). Furthermore, Crowe et al. (2008) reported a general decline in the total number of

357 waterbirds wintering in Ireland with waders exhibiting the greatest decrease although some

358 species showed an increasing trend. Range shifts and population fluctuations such as these

359 may in future influence observations of arrival and departure if the population ceases to use the

360 habitat where observations are being recorded. In addition, both intra- and inter-specific

361 competition on the breeding and wintering grounds will be impacted by changes in species'

362 relative abundance (Lehikoinen et al. 2013).

363 The winter NAO influences environmental conditions early in spring and when in a positive 364 phase food supply and habitat suitability for migrant birds are generally optimized over a 365 relatively large geographical area (Hüppo and Hüppo, 2003). This contrasts with the spring 366 temperature which represents a more restricted and local effect. The timing of departure of the 367 winter visitors showed stronger correlation with the winter North Atlantic Oscillation than the 368 timing of arrival of the spring visitors. However, this may reflect the low number of spring visitors 369 examined in the study. In general during a positive NAO phase the timing of departure was 370 earlier in the year but there were also exceptions indicating a high level of variability in 371 response.. The NAO has been reported to have a strong negative correlation with arrival of 372 spring migrants (passerines and non-passerines) in many locations in Europe (Žalakevičius et 373 al. 2009; Jonzén et al. 2006; Vähätalo, et al. 2004; Hüppop and Hüppop, 2003; Forchhammer, et 374 al. 2002), including Ireland (Donnelly et al. 2009) but there have also been reports of delays 375 (Jonzén et al. 2006) and no influence (Cotton 2003). Therefore, it was not surprising to see 376 variation between species in their response to such a large scale circulation patterns. 377 Interestingly, the NAO and local spring temperature more often than not (23 cases out of 26) 378 resulted in the same directional response of spring departure and arrival suggesting that both 379 large scale and local weather patterns have a similar influence on bird migration.

\section{Conclusions}

381 We have clearly demonstrated a strong relationship between climate and changes in both spring 382 departure and arrival of a number of migratory waterbirds to the eastern region of Ireland over a 383 24-year period. As with many previous reports, the trends were found to be species specific as 384 some birds advanced while others delayed the timing of departure. Furthermore, in some years 385 we observed sightings reported in every month indicating the potential for these migrants to 386 become residents in Ireland. Although we expected to find the majority of birds leaving earlier in 387 response to warming temperatures we found opposite mixed trend which may be related to the 388 short time series available. This result, combined with reports (from Finland) of species 
389 remaining longer in their breeding grounds, suggests that the duration of stay in Ireland may not 390 be changing but may be shifting to later in the season. The length of stay of these birds requires 391 further investigation both within Ireland and across Europe as a whole in order to track potential 392 shifts in migratory patterns at a more regional scale. A shift in the timing of migration will have 393 implications for competition for resources and territory at both the wintering and breeding 394 grounds. 


\section{Acknowledgements}

396 The authors would like to express their gratitude to the volunteers and staff who contributed data 397 to the BirdWatch Ireland East Coast Bird Reports. In addition, we would like to acknowledge Met 398 Éireann for supplying the temperature data. 
400

401

402

403

404

405

406

407

408

409

410

411

412

413

414

415

416

417

418

420

421

422

423

424 425

426

427

Alcamo, J., Moreno, J.M., Nováky, B., Bindi, M., Corobov, R., Devoy, R.J.N., Giannakopoulos, C., Martin, E., Olesen, J.E. and Shvidenko, A. 2007 Europe. Climate Change 2007: Impacts, Adaptation and Vulnerability. Contribution of Working Group II to the Fourth Assessment Report of the Intergovernmental Panel on Climate Change, M.L. Parry, O.F. Canziani, J.P. Palutikof, P.J. van der Linden and C.E. Hanson, Eds., Cambridge University Press, Cambridge, UK, 541-580.

Balbontín, J., Møller, A.P., Hermosell, I.G., Marzal, A., Reviriego, M. and de Lope, F. 2009 Individual responses in spring arrival date to ecological conditions during winter and migration in a migratory bird. Journal of Animal Ecology 78, 981-989.

Berthold, P. (2001) Bird Migration: A general survey. Oxford University Press, Oxford, UK.

Cook, B.I., Smith, T.M. and Mann, M.E. 2005 The North Atlantic Oscillation and regional phenology prediction over Europe. Global Change Biology 11, 919-926.

Cooney, T., Madden, B., O'Keeffe, P. and O'Flanagan, C.D. 1980 Irish East Coast Bird Report, BirdWatch Ireland (Irish Wildbird Conservancy), Dublin.

Cooney, T., Baslam, B., Madden, B., O'Keeffe, P. and O'Flanagan, C.D. 1981 Irish East Coast Bird Report, BirdWatch Ireland (Irish Wildbird Conservancy), Dublin.

Cooney, T., Baslam, B., Madden, B., O'Keeffe, P. and O'Flanagan, C.D. 1982 Irish East Coast Bird Report, BirdWatch Ireland (Irish Wildbird Conservancy), Dublin.

Cooney, T., Madden, B., O'Flanagan, C.D. and O'Keeffe, P. 1983 Irish East Coast Bird Report, BirdWatch Ireland (Irish Wildbird Conservancy), Dublin.

Cooney, T., Madden, B., O'Flanagan, C.D. and O'Keeffe, P. 1984 Irish East Coast Bird Report, BirdWatch Ireland (Irish Wildbird Conservancy), Dublin.

Cooney, T., Madden, B., O'Flanagan, C.D. and O'Keeffe, P. 1985 Irish East Coast Bird Report, BirdWatch Ireland (Irish Wildbird Conservancy), Dublin.

Cooney, T., Madden, B. and O'Flanagan, C.D. 1986 Irish East Coast Bird Report, BirdWatch Ireland (Irish Wildbird Conservancy), Dublin.

Cooney, T., Madden, B., O'Donnell, M., and O'Flanagan, C.D. 1987 Irish East Coast Bird Report, BirdWatch Ireland (Irish Wildbird Conservancy), Dublin. 
428 Cooney, T., Madden, B., O'Donnell, M., and O'Flanagan, C.D. 1988 Irish East Coast Bird Report, 429 BirdWatch Ireland (Irish Wildbird Conservancy), Dublin.

430 Cooney, T., Madden, B. and O'Donnell, M. 1989 Irish East Coast Bird Report, BirdWatch Ireland 431 (Irish Wildbird Conservancy), Dublin.

432 Cooney, T., Madden, B. and O'Donnell, M. 1990 Irish East Coast Bird Report, BirdWatch Ireland 433 (Irish Wildbird Conservancy), Dublin.

434 Cooney, T., Madden, B. and O’Donnell, M. 1991 Irish East Coast Bird Report, BirdWatch Ireland 435 (Irish Wildbird Conservancy), Dublin.

436 Cooney, T. and Madden, B. 1992 Irish East Coast Bird Report, BirdWatch Ireland (Irish Wildbird 437 Conservancy), Dublin.

438 Cooney, T. and Madden, B. 1993 Irish East Coast Bird Report, BirdWatch Ireland (Irish Wildbird 439 Conservancy), Dublin.

440 Cooney, T. and Madden, B. 1994 Irish East Coast Bird Report, BirdWatch Ireland (Irish Wildbird 441 Conservancy), Dublin.

442 Cooney, T. and Madden, B. 1995 Irish East Coast Bird Report, BirdWatch Ireland (Irish Wildbird 443 Conservancy), Dublin.

444 Madden, B. and Cooney, T. 1996 Irish East Coast Bird Report, BirdWatch Ireland (Irish Wildbird 445 Conservancy), Dublin.

446 Madden, B. 1998 Irish East Coast Bird Report, BirdWatch Ireland (Irish Wildbird Conservancy), 447 Dublin.

448 Madden, B. and Cooney, T. 1999 Irish East Coast Bird Report, BirdWatch Ireland (Irish Wildbird 449 Conservancy), Dublin.

450 Coombes, R.H. and Murphy, D.F. 2000 Irish East Coast Bird Report, BirdWatch Ireland (Irish 451 Wildbird Conservancy), Dublin.

452 Coombes, R.H. and Murphy, D.F. 2001 Irish East Coast Bird Report, BirdWatch Ireland (Irish 453 Wildbird Conservancy), Dublin.

454 Coombes, R.H. and Murphy, D.F. 2002 Irish East Coast Bird Report, BirdWatch Ireland (Irish $455 \quad$ Wildbird Conservancy), Dublin. 
456 Coombes, R.H. and Murphy, D.F. 2003 Irish East Coast Bird Report, BirdWatch Ireland (Irish 457 Wildbird Conservancy), Dublin.

458 Cotton, P.A. 2003 Avian migration phenology and global climate change. Proceedings of the $459 \quad$ National Academy of Science, USA 100, 12219-12222.

460 Crick, H.Q.P. 2004 The impact of climate change on birds. Ibis 146, 48-56.

461 Crowe, O., Austin, G.E., Colhoun, K., Cranswick, P.A., Kershaw, M. and Musgrove, A.J. 2008 $462 \quad$ Estimates and trends of waterbird numbers wintering in Ireland. Bird Study 55, 66-77.

463 Donnelly, A., Salamin, N. and Jones, M.B. 2006 Changes in tree phenology: an indicator of 464 spring warming in Ireland? Biology and Environment: Proceedings of the Royal Irish $465 \quad$ Academy 106(1), 47-55.

466 Donnelly, A., Cooney, T., Jennings, E., Buscardo, E. and Jones, M.B. 2009 Response of birds to 467 climatic variability; evidence from the western fringe of Europe. International Journal of 468 Biometeorology 53, 211-220.

469 Donnelly, A., Yu, R. and Liu, L. 2014 Trophic level responses differ as climate warms in Ireland. $470 \quad$ International Journal of Biometeorology (DOI 10.1007/s00484-014-0914-5).

471 Forchhammer, M.C., Post, E. and Stenseth, N.C. 2002 North Atlantic Oscillation timing of long472 and short-distance migration. Journal of Animal Ecology 71, 1002-1014.

473 Goodkin, N., Hughen, K.A., Doney, S.C. and Curry, W.B. 2008 Increased multidecadal variability 474 of the North Atlantic Oscillation since 1781. Nature GeoScience 1, 844-848.

475 Hüppop, O. and Hüppop, K. 2003 North Atlantic Oscillation and timing of spring migration in 476 birds. Proceedings of the Royal Society of London, Series B 270, 233-240.

477 Hurrell, J.W. 1995 Decadal trends in the North Atlantic Oscillation: regional temperatures and 478 precipitation. Science 269(5224), 676-679.

479 Hurrell, J.W. and Van Loon, H. 1997 Decadal variations in climate associated with the North $480 \quad$ Atlantic Oscillation. Climate Change 36, 301-326.

481 Hurrell, J.W. and Trenberth, K.E. 2010 Climate change. In: Møller, A.P., Fiedler, W. and Berthold, 482 P. (eds.) Effects of climate change on birds. London: Oxford University Press, 9-38.

483 IPCC, 2007 Climate Change 2007: Impacts, Adaptation and Vulnerability. Contribution of $484 \quad$ Working Group II to the Fourth Assessment Report of the Intergovernmental Panel on 
485

Climate Change, Parry, M.L., Canziani, O.F., Palutikof, J.P., van der Linden, P.J and Hanson, C.E., Eds., Cambridge University Press, Cambridge, UK, 976 pp.

IPCC, 2013 Climate Change 2013: The Physical Science Basis. Contribution of Working Group I to the Fifth Assessment Report of the Intergovernmental Panel on Climate Change, Stocker, T.F., Qin, D., Plattner, G.-K., Tignor, M.M.B., Allen, S.K., Boschung, J., Nauels, A., Xia, Y., Bex, V. and Midgley, P. Eds., Cambridge University Press, Cambridge, UK, and New York, NY, USA, 1535 pp.

Jonzén, N., Lindén, A. and Ergon, T. 2006 Rapid advance of spring arrival dates in long-distance migratory birds. Science 312, 1959-1961.

Knudsen, E., Lindén, A., Both, C., Jonzén, N., Pulido, F., Saino, N., Sutherland, W.J., Bach, L.A., Coppack, T., Ergon, T., Gienapp, P., Gill, J.A., Gordo, O., Hedenström, A., Lehikoinen, E., Marra, P.P., Møller, A.P., Nilsson, A.L.K., Péron, G., Ranta, E., Rubolini, D., Sparks, T.H., Spina, F., Studds, C.E., Sæther, S.A., Tryjanowski, P. and Stenseth, N.C. 2011 Challenging claims in the study of migratory birds and climate change. Biological Reviews 86, 928-946.

Lehikoinen, A. and Jaatinen, K. 2011 Delayed autumn migration in northern European wildfowl. Journal of Ornithology 153, 563-570.

Lehikoinen, A., Jaatinen, K., Vähätalo, A.V., Clausen, P., Crowe, O., Deceuninck, B., Hearn, R., Holt, C.A., Hornman, M., Keller, V., Nilsson, L., Langerdoen, T., Tománková, I., Wahl, J. and Fox, A.D. 2013 Rapid climate driven shifts in wintering distributions of three common waterbird species. Global Change Biology 19, 2071-2081.

Libiseller ,C. and Grimvall, A. (2002) Performance of Mann-Kendall test for trend detection in the presence of covariates. Environmetrics 13, 71-84.

Miller-Rushing, A.J., Lloyd-Evans, T.L., Primak, R.B. and Sarzinger, P. (2008) Bird migration times, climate change, and changing population sizes. Global Change Biology 14, 19591972.

Møller, A.P., Fielder, W. and Berthold, P. 2010 Introduction. In: Møller, A.P., W. Fielder and P. Berthold (eds.). The effects of climate change on birds. New York: Oxford University Press, 3-5.

O'Reilly, K.M. and Wingfield, J. 1995 Spring and Autumn migration in Arctic shorebirds: same distance, different strategies. Integrative and Comparative Biology 35, 222-233. 
515 Richardson, A.D., Bailey, A.S., Denny, E.G., Martin, C.W. and O'Keefe, J. 2006 A multi-site 516 analysis of random error in tower-based measurements of carbon and energy fluxes. $517 \quad$ Agriculture and Forest Meteorology 136, 1-18.

518 Rubolini, A., Møller, A.P., Rainio, K. and Lehikoinen, E. 2007 Intraspecific consistency and 519 geographic variability in temporal trends of spring migration phenology among European $520 \quad$ bird species. Climate Research 35, 135-146.

521 Sparks, T.H., Roberts, D.R. and Crick, H.Q.P. 2001 What is the value of first arrival dates of 522 spring migrants in phenology? Avian Ecology and Behaviour 7, 75-85.

523 Sparks, T.H., Huber, K. and Tryjanowski, P. 2008 Something for the weekend? Examining the 524 biasin avail phenological recording. International Journal of Biometeorology 52, 505-510.

525 Stenseth, N.C., Ottersen, G., Hurrell, J.W., Mysterud, A., Lima, M., Chan, K.-S., Yoccoz, N.G. 526 and Ådlandsvik, B. 2003 Studying climate effects on ecology through the use of climate 527 indices: the North Atlantic Oscillation, El Niño Southern Oscillation and beyond. 528 Proceedings of the Royal Society of London Series B 270, 2087-2096.

529 Stirnemann, R.L., O'Halloran, J., Ridgway, M. and Donnelly, A. 2012 Temperature related 530 increases in grass growth and greater competition for food drive earlier migrational 531 departure of wintering Whooper Swan. Ibis 154, 542-553.

532 UNEP and CMS 2011 A review of CMS and non-CMS existing administrative/management 533 instruments for migratory birds globally 534 (http://www.cms.int/sites/default/files/document/inf_04_1b_flyway_wg_review1_e_only_0.p $535 \mathrm{df})$.

536 Vähätalo, A.V., Rainio, K., Lehikoinen, A. and Lehikoinen, E. 2004 Spring arrival of birds 537 depends on the North Atlantic Oscillation. Journal of Avian Biology 35, 210-216.

538 Visbeck, M.H. Hurrell, J.W., Polvani, L. and Cullen, H.M. 2001 The North Atlantic Oscillation: 539 past, present and future. Proceedings of the National Academy of Sciences of the United $540 \quad$ States of America 98, 12876-12877.

541 Wahlin, K. and Grimcall, A. 2010 Roadmap for assessing regional trends in groundwater quality. $542 \quad$ Environmental Monitoring and Assessment 165, 217-231. 
543 Žalakevičius, M., Bartkevičiene, G., Ivanauskas, F. and Nedzinskas, V. 2009 The response of 544 spring arrival dates of non-passerine migrants to climate change: a case study from $545 \quad$ Eastern Baltic. Acta Zoologica Lituanica 19, 155-171. 


\section{Table $\mathbf{1}_{\text {(on next page) }}$}

Table 1

Common and scientific names of the bird species together with category, diver, waterfowl or wader; ' $\mathrm{N}$ Year' number of records in the time series; 'N Bird' average number of birds reported per year together with the Standard Deviation; MK-Stat results of the Mann-Kendall test to determine trends over time and significance level (P); numbers in bold are statistically significant. Earliest, average and latest DOY (day of year) refers to the data extracted from the Irish East Coast Bird Reports (1980-2003) for each individual species. 


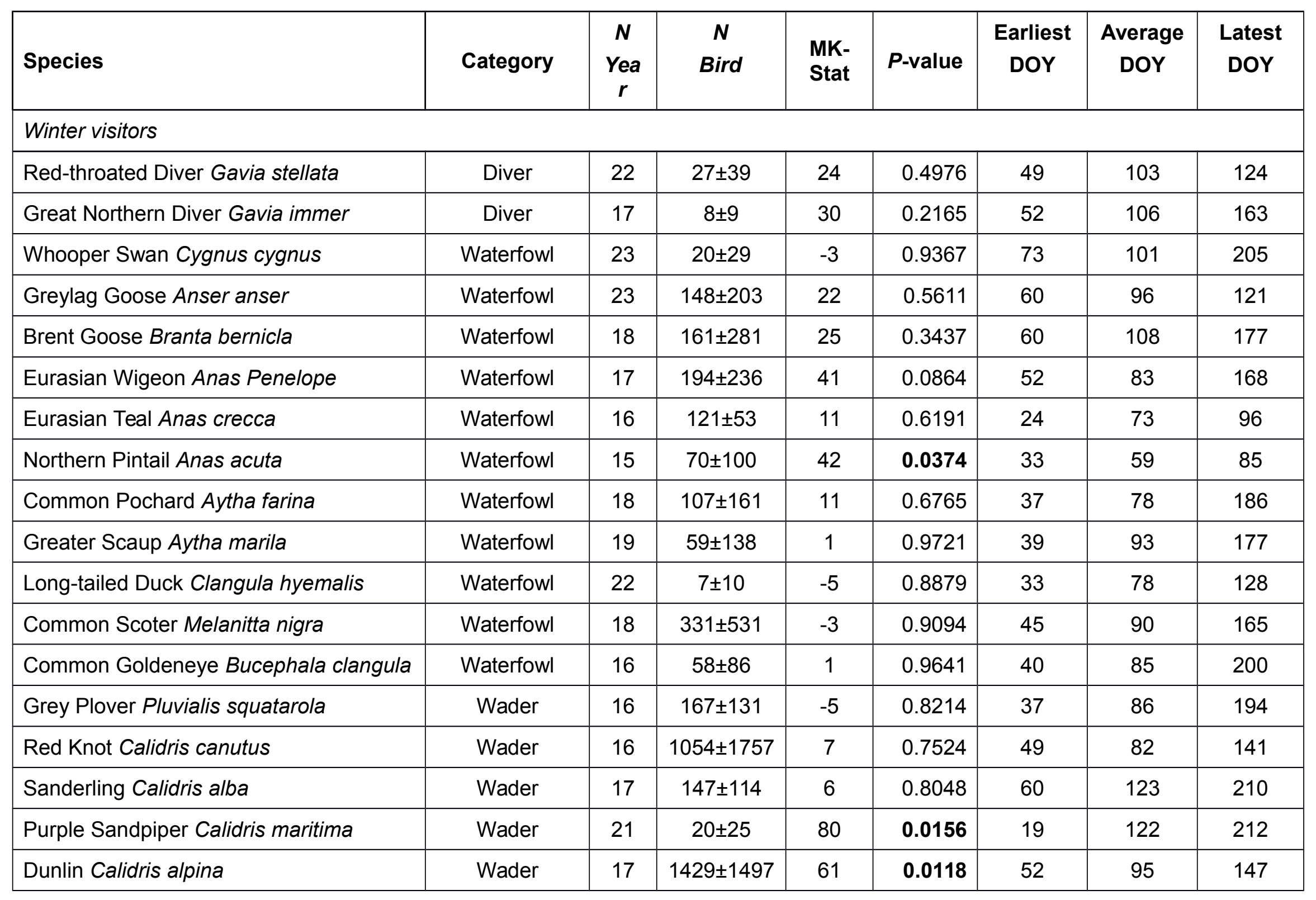




\begin{tabular}{|c|c|c|c|c|c|c|c|c|}
\hline Jack Snipe Lymncryptes minimus & Wader & 20 & $2 \pm 3$ & -35 & 0.2559 & 29 & 70 & 104 \\
\hline Bar-tailed Godwit Limosa lapponica & Wader & 15 & $326 \pm 281$ & -25 & 0.2160 & 52 & 114 & 201 \\
\hline Common Redshank Tringa tetanus & Wader & 18 & $558 \pm 350$ & 3 & 0.9094 & 43 & 84 & 111 \\
\hline Common Greenshank Tringa nebularia & Wader & 15 & $15 \pm 12$ & -47 & 0.0200 & 32 & 106 & 196 \\
\hline \multicolumn{9}{|l|}{ Summer visitors } \\
\hline Manx Shearwater Puffinus puffinus & Diver & 20 & $626 \pm 1801$ & -16 & 0.6028 & 78 & 124 & 163 \\
\hline Sandwich Tern Sterna sandvicensis & Diver & 22 & $2 \pm 2$ & -117 & 0.0009 & 71 & 85 & 103 \\
\hline
\end{tabular}




\section{Table 2 (on next page)}

Table 2

Linear regression slopes $\pm \mathrm{SE}, \mathrm{R} 2$ and $\mathrm{P}$ values for latest (winter visitors) records (DOY) and earliest (summer visitors) records (DOY) of migrant waterbirds to the east coast of Ireland and (i) average monthly local spring temperatures (January-April; and average February to April) (OC) and (ii) the North Atlantic Oscillation Index (NAOI). 


\begin{tabular}{|c|c|c|c|c|c|c|c|c|c|c|c|c|c|c|c|c|c|c|}
\hline \multirow[b]{2}{*}{ Species } & \multicolumn{3}{|l|}{ Jan } & \multicolumn{3}{|l|}{ Feb } & \multicolumn{3}{|l|}{ Mar } & \multicolumn{3}{|l|}{ Apr } & \multicolumn{3}{|l|}{$F-A$} & \multicolumn{3}{|l|}{ NAOI } \\
\hline & $\begin{array}{l}\text { Slope } \pm \\
\text { SE }\end{array}$ & $R^{2}$ & $P$ & $\begin{array}{l}\text { Slope } \pm \\
\text { SE }\end{array}$ & $R^{2}$ & $P$ & $\begin{array}{l}\text { Slope } \pm \\
\text { SE }\end{array}$ & $R^{2}$ & $P$ & $\begin{array}{l}\text { Slope } \pm \\
\text { SE }\end{array}$ & $R^{2}$ & $P$ & $\begin{array}{l}\text { Slope } \pm \\
\text { SE }\end{array}$ & $R^{2}$ & $P$ & $\begin{array}{l}\text { Slope } \pm \\
\text { SE }\end{array}$ & $R^{2}$ & $P$ \\
\hline \multicolumn{19}{|l|}{ Winter visitors } \\
\hline $\begin{array}{l}\text { Red-throated } \\
\text { Diver }\end{array}$ & $\begin{array}{l}-4.245 \pm \\
2.99\end{array}$ & 0.092 & 0.170 & $\begin{array}{l}-2.935 \pm \\
2.63\end{array}$ & 0.059 & 0.278 & $\begin{array}{l}-6.344 \pm \\
3.10\end{array}$ & 0.173 & 0.054 & $\begin{array}{l}-0.690 \pm \\
3.87\end{array}$ & 0.002 & 0.860 & $\begin{array}{l}-7.816 \pm \\
4.54\end{array}$ & $\begin{array}{l}0.12 \\
9\end{array}$ & 0.101 & $\begin{array}{l}-9.030 \pm \\
2.54\end{array}$ & 0.386 & 0.002 \\
\hline $\begin{array}{l}\text { Great Northern } \\
\text { Diver }\end{array}$ & $\begin{array}{l}0.410 \pm \\
7.14\end{array}$ & 0.000 & 0.955 & $\begin{array}{l}5.307 \pm \\
5.47\end{array}$ & 0.059 & 0.347 & $\begin{array}{l}0.705 \pm \\
7.36\end{array}$ & 0.001 & 0.925 & $\begin{array}{l}9.384 \pm \\
8.73\end{array}$ & 0.071 & 0.300 & $\begin{array}{l}10.554 \\
\pm 10.01\end{array}$ & $\begin{array}{l}0.06 \\
9\end{array}$ & 0.309 & $\begin{array}{l}1.245 \pm \\
7.06\end{array}$ & 0.002 & 0.862 \\
\hline Whooper Swan & $\begin{array}{l}0.191 \pm \\
5.46\end{array}$ & 0.000 & 0.972 & $\begin{array}{l}-4.029 \pm \\
4.55\end{array}$ & 0.036 & 0.385 & $\begin{array}{l}11.881 \pm \\
5.50\end{array}$ & 0.182 & 0.042 & $\begin{array}{l}-3.615 \pm \\
6.37\end{array}$ & 0.015 & 0.576 & $\begin{array}{l}1.059 \pm \\
8.28\end{array}$ & $\begin{array}{l}0.00 \\
1\end{array}$ & 0.899 & $\begin{array}{l}-0.692 \pm \\
5.74\end{array}$ & 0.001 & 0.905 \\
\hline Greylag Goose & $\begin{array}{l}4.630 \pm \\
2.66\end{array}$ & 0.126 & 0.097 & $\begin{array}{l}-1.316 \pm \\
2.40\end{array}$ & 0.014 & 0.589 & $\begin{array}{l}5.287 \pm \\
2.95\end{array}$ & 0.133 & 0.088 & $\begin{array}{l}-2.714 \pm \\
3.30\end{array}$ & 0.031 & 0.420 & $\begin{array}{l}0.366 \pm \\
4.32\end{array}$ & $\begin{array}{l}0.00 \\
0\end{array}$ & 0.933 & $\begin{array}{l}4.501 \pm \\
2.83\end{array}$ & 0.108 & 0.126 \\
\hline Brent Goose & $\begin{array}{l}-3.061 \pm \\
7.37\end{array}$ & 0.011 & 0.683 & $\begin{array}{l}-6.933 \pm \\
5.87\end{array}$ & 0.080 & 0.254 & $\begin{array}{l}-7.203 \pm \\
6.77\end{array}$ & 0.066 & 0.303 & $\begin{array}{l}1.326 \pm \\
7.90\end{array}$ & 0.002 & 0.869 & $\begin{array}{l}-13.863 \\
\pm 11.04\end{array}$ & $\begin{array}{l}0.09 \\
0\end{array}$ & 0.227 & $\begin{array}{l}-9.399 \pm \\
6.121\end{array}$ & 0.128 & 0.144 \\
\hline $\begin{array}{l}\text { Eurasian } \\
\text { Wigeon }\end{array}$ & $\begin{array}{l}-0.714 \pm \\
6.54\end{array}$ & 0.001 & 0.915 & $\begin{array}{l}-7.670 \pm \\
4.75\end{array}$ & 0.148 & 0.127 & $\begin{array}{l}-0.355 \pm \\
6.99\end{array}$ & 0.000 & 0.960 & $\begin{array}{l}-13.018 \\
\pm 7.01\end{array}$ & 0.187 & 0.083 & $\begin{array}{l}-16.462 \\
\pm 8.85\end{array}$ & $\begin{array}{l}0.18 \\
7\end{array}$ & 0.083 & $\begin{array}{l}-0.084 \pm \\
6.26\end{array}$ & 0.000 & 0.990 \\
\hline Eurasian Teal & $\begin{array}{l}0.918 \pm \\
3.94\end{array}$ & 0.004 & 0.819 & $\begin{array}{l}-3.916 \pm \\
3.02\end{array}$ & 0.107 & 0.216 & $\begin{array}{l}1.101 \pm \\
4.42\end{array}$ & 0.066 & 0.807 & $\begin{array}{l}-4.181 \pm \\
4.88\end{array}$ & 0.50 & 0.406 & $\begin{array}{l}-5.607 \pm \\
5.64\end{array}$ & $\begin{array}{l}0.25 \\
7\end{array}$ & 0.337 & $\begin{array}{l}-1.510 \pm \\
3.81\end{array}$ & 0.105 & 0.698 \\
\hline Northern Pintail & $\begin{array}{l}-0.649 \pm \\
3.89\end{array}$ & 0.002 & 0.870 & $\begin{array}{l}-5.916 \pm \\
2.13\end{array}$ & 0.392 & 0.017 & $\begin{array}{l}-8.049 \pm \\
2.98\end{array}$ & 0.378 & 0.019 & $\begin{array}{l}0.130 \pm \\
4.20\end{array}$ & 0.000 & 0.976 & $\begin{array}{l}-10.443 \\
\pm 3.75\end{array}$ & $\begin{array}{l}0.39 \\
2\end{array}$ & 0.017 & $\begin{array}{l}-6.293 \pm \\
3.23\end{array}$ & 0.240 & 0.075 \\
\hline $\begin{array}{l}\text { Common } \\
\text { Pochard }\end{array}$ & $\begin{array}{l}8.743 \pm \\
8.24\end{array}$ & 0.066 & 0.304 & $\begin{array}{l}4.961 \pm \\
6.52\end{array}$ & 0.035 & 0.458 & $\begin{array}{l}8.571 \pm \\
8.44\end{array}$ & 0.061 & 0.325 & $\begin{array}{l}9.069 \pm \\
10.27\end{array}$ & 0.047 & 0.390 & $\begin{array}{l}14.173 \\
\pm 11.21\end{array}$ & $\begin{array}{l}0.09 \\
1\end{array}$ & 0.224 & $\begin{array}{l}11.549 \\
\pm 9.03\end{array}$ & 0.093 & 0.219 \\
\hline Greater Scaup & $\begin{array}{l}7.638 \pm \\
8.10\end{array}$ & 0.050 & 0.359 & $\begin{array}{l}6.396 \pm \\
6.82\end{array}$ & 0.049 & 0.361 & $\begin{array}{l}10.266 \pm \\
9.08\end{array}$ & 0.070 & 0.274 & $\begin{array}{l}-1.138 \pm \\
10.42\end{array}$ & 0.001 & 0.914 & $\begin{array}{l}13.660 \\
\pm 12.75\end{array}$ & $\begin{array}{l}0.06 \\
3\end{array}$ & 0.299 & $\begin{array}{l}18.328 \pm \\
7.96\end{array}$ & 0.238 & 0.034 \\
\hline Long-tailed Duck & $\begin{array}{l}3.883 \pm \\
3.77\end{array}$ & 0.050 & 0.317 & $\begin{array}{l}-5.488 \pm \\
3.13\end{array}$ & 0.133 & 0.095 & $\begin{array}{l}-0.611 \pm \\
4.23\end{array}$ & 0.001 & 0.887 & $\begin{array}{l}-6.035 \pm \\
4.62\end{array}$ & 0.079 & 0.206 & $\begin{array}{l}-9.477 \pm \\
5.65\end{array}$ & $\begin{array}{l}0.12 \\
3\end{array}$ & 0.109 & $\begin{array}{l}-2.240 \pm \\
4.00\end{array}$ & 0.015 & 0.582 \\
\hline Common Scoter & $\begin{array}{l}-5.834 \pm \\
6.22\end{array}$ & 0.052 & 0.362 & $\begin{array}{l}7.072 \pm \\
4.81\end{array}$ & 0.003 & 0.827 & $\begin{array}{l}3.048 \pm \\
6.97\end{array}$ & 0.012 & 0.668 & $\begin{array}{l}0.725 \pm \\
6.66\end{array}$ & 0.001 & 0.915 & $\begin{array}{l}3.257 \pm \\
08.82\end{array}$ & $\begin{array}{l}0.00 \\
8\end{array}$ & 0.717 & $\begin{array}{l}1.872 \pm \\
6.41\end{array}$ & 0.005 & 0.774 \\
\hline $\begin{array}{l}\text { Common } \\
\text { Goldeneye }\end{array}$ & $\begin{array}{l}6.724 \pm \\
11.28\end{array}$ & 0.025 & 0.561 & $\begin{array}{l}1.608 \pm \\
8.03\end{array}$ & 0.003 & 0.844 & $\begin{array}{l}3.546 \pm \\
10.73\end{array}$ & 0.008 & 0.746 & $\begin{array}{l}-0.408 \pm \\
12.52\end{array}$ & 0.000 & 0.974 & $\begin{array}{l}4.179 \pm \\
15.36\end{array}$ & $\begin{array}{l}0.00 \\
5\end{array}$ & 0.790 & $\begin{array}{l}22.60 \pm \\
9.62\end{array}$ & 0.283 & 0.034 \\
\hline Grey Plover & $\begin{array}{l}-19.623 \\
\pm 9.50\end{array}$ & 0.233 & 0.054 & $\begin{array}{l}-10.515 \\
\pm 7.20\end{array}$ & 0.132 & 0.166 & $\begin{array}{l}-14.105 \\
\pm 10.42\end{array}$ & 0.116 & 0.197 & $\begin{array}{l}-8.181 \pm \\
11.61\end{array}$ & 0.034 & 0.493 & $\begin{array}{l}-25.017 \\
\pm 13.04\end{array}$ & $\begin{array}{l}0.20 \\
8\end{array}$ & 0.076 & $\begin{array}{l}-17.040 \\
\pm 10.13\end{array}$ & 0.168 & 0.115 \\
\hline Red Knot & $4.673 \pm$ & 0.044 & 0.433 & $1.441 \pm$ & 0.008 & 0.747 & $5.180 \pm$ & 0.060 & 0.362 & $6.226 \pm$ & 0.050 & 0.405 & $7.289 \pm$ & 0.06 & 0.359 & $4.490 \pm$ & 0.048 & 0.417 \\
\hline
\end{tabular}




\begin{tabular}{|c|c|c|c|c|c|c|c|c|c|c|c|c|c|c|c|c|c|c|}
\hline & 5.75 & & & 4.39 & & & 5.50 & & & 7.25 & & & 7.68 & 0 & & 5.37 & & \\
\hline Sanderling & $\begin{array}{l}1.141 \pm \\
8.67\end{array}$ & 0.001 & 0.897 & $\begin{array}{l}-8.551 \pm \\
6.23\end{array}$ & 0.112 & 0.190 & $\begin{array}{l}-6.668 \pm \\
9.71\end{array}$ & 0.030 & 0.503 & $\begin{array}{l}-2.569 \pm \\
10.38\end{array}$ & 0.004 & 0.808 & $\begin{array}{l}-14.185 \\
\pm 11.59\end{array}$ & $\begin{array}{l}0.09 \\
1\end{array}$ & 0.240 & $\begin{array}{l}-10.091 \\
\pm 7.88\end{array}$ & 0.098 & 0.220 \\
\hline $\begin{array}{l}\text { Purple } \\
\text { Sandpiper }\end{array}$ & $\begin{array}{l}11.659 \pm \\
7.83\end{array}$ & 0.105 & 0.153 & $\begin{array}{l}6.429 \pm \\
6.46\end{array}$ & 0.050 & 0.332 & $\begin{array}{l}5.413 \pm \\
8.59\end{array}$ & 0.020 & 0.536 & $\begin{array}{l}12.690 \pm \\
9.41\end{array}$ & 0.087 & 0.193 & $\begin{array}{l}16.499 \\
\pm 11.29\end{array}$ & $\begin{array}{l}0.10 \\
1\end{array}$ & 0.160 & $\begin{array}{l}11.111 \pm \\
8.09\end{array}$ & 0.090 & 0.186 \\
\hline Dunlin & $\begin{array}{l}6.206 \pm \\
7.62\end{array}$ & 0.042 & 0.428 & $\begin{array}{l}5.414 \pm \\
5.66\end{array}$ & 0.057 & 0.354 & $\begin{array}{l}4.283 \pm \\
7.82\end{array}$ & 0.020 & 0.592 & $\begin{array}{l}2.816 \pm \\
9.19\end{array}$ & 0.006 & 0.764 & $\begin{array}{l}10.227 \\
\pm 10.52\end{array}$ & $\begin{array}{l}0.05 \\
9\end{array}$ & 0.346 & $\begin{array}{l}-0.227 \pm \\
7.54\end{array}$ & 0.000 & 0.976 \\
\hline Jack Snipe & $\begin{array}{l}-3.104 \pm \\
4.05\end{array}$ & 0.032 & 0.454 & $\begin{array}{l}-2.269 \pm \\
3.11\end{array}$ & 0.029 & 0.474 & $\begin{array}{l}-0.687 \pm \\
4.22\end{array}$ & 0.001 & 0.873 & $\begin{array}{l}-1.299 \pm \\
4.40\end{array}$ & 0.005 & 0.771 & $\begin{array}{l}-3.485 \pm \\
5.54\end{array}$ & $\begin{array}{l}0.02 \\
2\end{array}$ & 0.537 & $\begin{array}{l}-6.848 \pm \\
3.70\end{array}$ & 0.160 & 0.081 \\
\hline $\begin{array}{l}\text { Black-tailed } \\
\text { Godwit }\end{array}$ & $\begin{array}{l}-4.024 \pm \\
5.84\end{array}$ & 0.027 & 0.500 & $\begin{array}{l}-6.126 \pm \\
5.69\end{array}$ & 0.064 & 0.297 & $\begin{array}{l}0.081 \pm \\
6.64\end{array}$ & 0.000 & 0.990 & $\begin{array}{l}-5.269 \pm \\
8.20\end{array}$ & 0.024 & 0.529 & $\begin{array}{l}-10.475 \\
\pm 10.88\end{array}$ & $\begin{array}{l}0.05 \\
2\end{array}$ & 0.349 & $\begin{array}{l}-3.841 \pm \\
6.05\end{array}$ & 0.023 & 0.534 \\
\hline $\begin{array}{l}\text { Bar-tailed } \\
\text { Godwit }\end{array}$ & $\begin{array}{l}-12.922 \\
\pm 11.47\end{array}$ & 0.089 & 0.280 & $\begin{array}{l}-1.287 \pm \\
10.80\end{array}$ & 0.001 & 0.907 & $\begin{array}{l}3.437 \pm \\
13.44\end{array}$ & 0.005 & 0.802 & $\begin{array}{l}-4.519 \pm \\
15.52\end{array}$ & 0.006 & 0.776 & $\begin{array}{l}-1.796 \pm \\
22.40\end{array}$ & $\begin{array}{l}0.00 \\
0\end{array}$ & 0.937 & $\begin{array}{l}3.403 \pm \\
11.28\end{array}$ & 0.007 & 0.768 \\
\hline $\begin{array}{l}\text { Common } \\
\text { Redshank }\end{array}$ & $\begin{array}{l}-1.548 \pm \\
3.95\end{array}$ & 0.010 & 0.700 & $\begin{array}{l}1.630 \pm \\
3.09\end{array}$ & 0.017 & 0.605 & $\begin{array}{l}-0.688 \pm \\
3.95\end{array}$ & 0.002 & 0.864 & $\begin{array}{l}3.457 \pm \\
4.43\end{array}$ & 0.037 & 0.447 & $\begin{array}{l}2.806 \pm \\
5.31\end{array}$ & $\begin{array}{l}0.01 \\
7\end{array}$ & 0.605 & $\begin{array}{l}2.571 \pm \\
3.75\end{array}$ & 0.029 & 0.502 \\
\hline $\begin{array}{l}\text { Common } \\
\text { Greenshank }\end{array}$ & $\begin{array}{l}2.872 \pm \\
11.47\end{array}$ & 0.005 & 0.806 & $\begin{array}{l}-8.566 \pm \\
8.76\end{array}$ & 0.069 & 0.346 & $\begin{array}{l}11.622 \pm \\
11.78\end{array}$ & 0.070 & 0.342 & $\begin{array}{l}-1.477 \pm \\
13.47\end{array}$ & 0.001 & 0.914 & $\begin{array}{l}-3.062 \pm \\
16.38\end{array}$ & $\begin{array}{l}0.00 \\
3\end{array}$ & 0.855 & $\begin{array}{l}-3.249 \pm \\
10.83\end{array}$ & 0.007 & 0.769 \\
\hline $\begin{array}{l}\text { Ruddy } \\
\text { Turnstone }\end{array}$ & $\begin{array}{l}1.669 \pm \\
8.35\end{array}$ & 0.003 & 0.845 & $\begin{array}{l}-10.354 \\
\pm 6.25\end{array}$ & 0.174 & 0.122 & $\begin{array}{l}-4.142 \pm \\
8.32\end{array}$ & 0.019 & 0.627 & $\begin{array}{l}-2.134 \pm \\
10.41\end{array}$ & 0.003 & 0.841 & $\begin{array}{l}-18.942 \\
\pm 12.80\end{array}$ & $\begin{array}{l}0.14 \\
4\end{array}$ & 0.163 & $\begin{array}{l}-5.837 \pm \\
7.37\end{array}$ & 0.046 & 0.443 \\
\hline \multicolumn{19}{|l|}{ Summer visitors } \\
\hline $\begin{array}{l}\text { Manx } \\
\text { Shearwater }\end{array}$ & $\begin{array}{l}-1.675 \pm \\
4.31\end{array}$ & 0.008 & 0.702 & $\begin{array}{l}-0.616 \pm \\
3.81\end{array}$ & 0.001 & 0.874 & $\begin{array}{l}-5.672 \pm \\
4.75\end{array}$ & 0.073 & 0.248 & $\begin{array}{l}4.317 \pm \\
5.20\end{array}$ & 0.037 & 0.417 & $\begin{array}{l}-1.838 \pm \\
6.74\end{array}$ & $\begin{array}{l}0.00 \\
4\end{array}$ & 0.788 & $\begin{array}{l}-1.753 \pm \\
4.64\end{array}$ & 0.008 & 0.710 \\
\hline Sandwich Tern & $\begin{array}{l}-1.359 \pm \\
1.57\end{array}$ & 0.036 & 0.396 & $\begin{array}{l}0.937 \pm \\
1.29\end{array}$ & 0.026 & 0.477 & $\begin{array}{l}-0.617 \pm \\
1.78\end{array}$ & 0.006 & 0.732 & $\begin{array}{l}0.884 \pm \\
1.89\end{array}$ & 0.011 & 0.644 & $\begin{array}{l}1.084 \pm \\
2.32\end{array}$ & 0.011 & 0.646 & $\begin{array}{l}1.156 \pm \\
1.63\end{array}$ & 0.025 & 0.486 \\
\hline
\end{tabular}


Figure 1 (on next page)

Figure 1

Location of the East coast region of Ireland (includes the counties, North to South Louth, Meath, Dublin and Wicklow) where the bird data were recorded and the two synoptic weather stations (T1: Dublin Airport and T2: Casement Aerodrome) used for temperature data. 


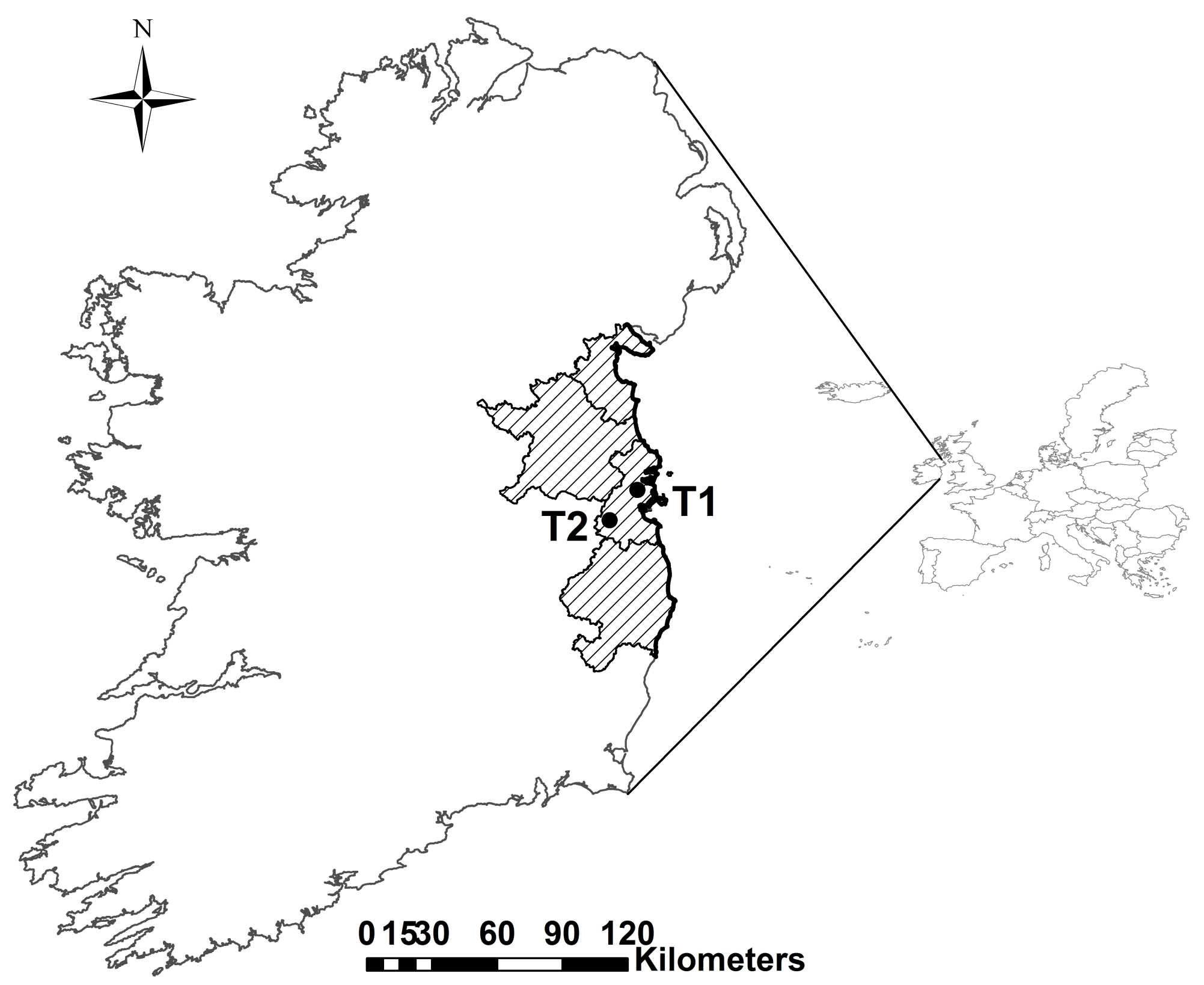


Figure 2 (on next page)

Figure 2

Average spring (February-April) temperature on the east coast of Ireland for the period 19802003 showing a statistically significant increasing trend. 


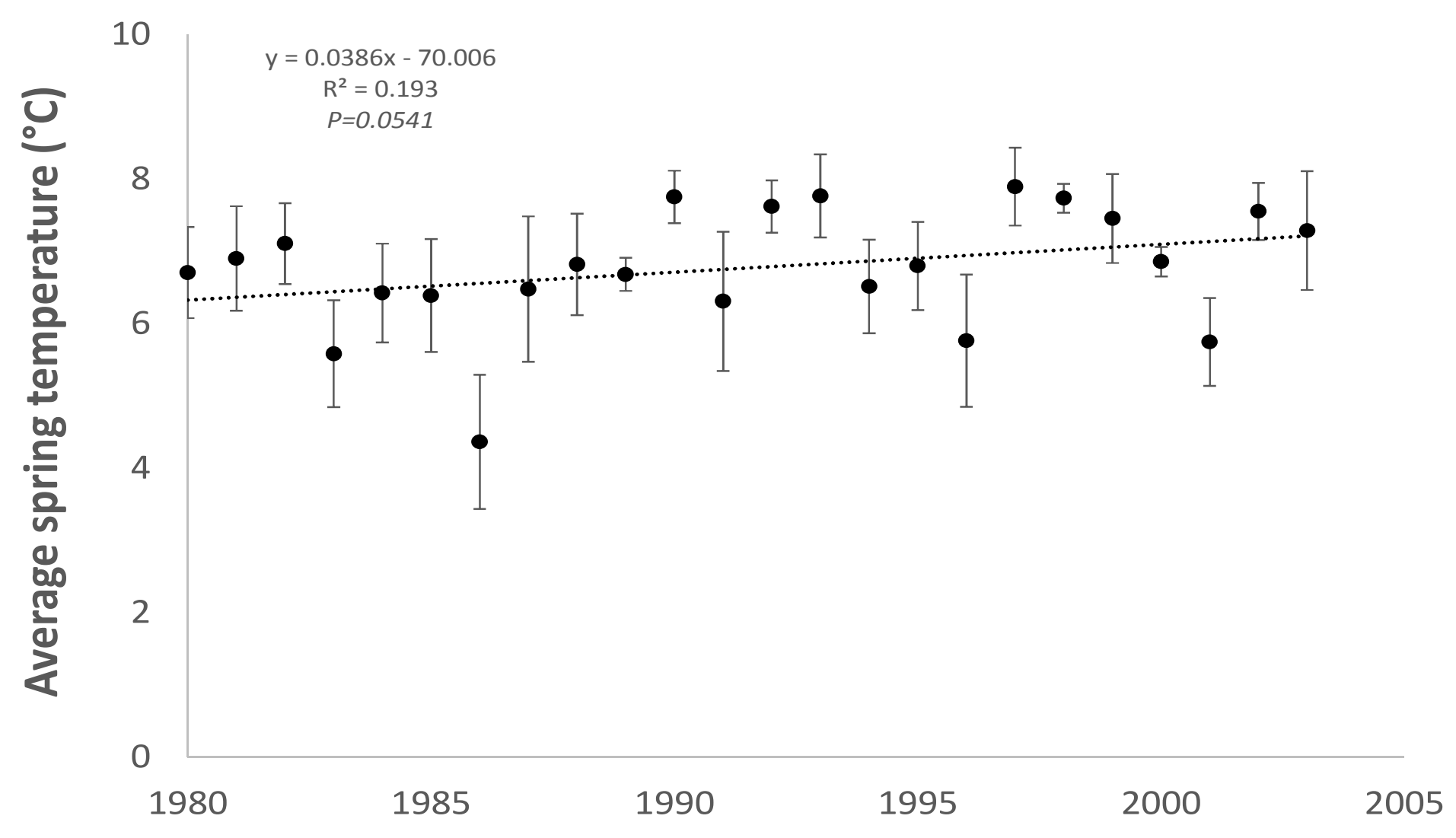


Figure 3 (on next page)

Figure 3

Trends in the timing of (a) the latest recorded date in spring (indicator for departure) when Dunlin, a winter visitor was observed and (b) the earliest recorded date in spring (indicator for arrival) when Sandwich Tern, a spring/summer visitor was observed, in the east coast region of Ireland over the time period 1980-2003. 


\section{PeerJ Reviewing Manuscript}

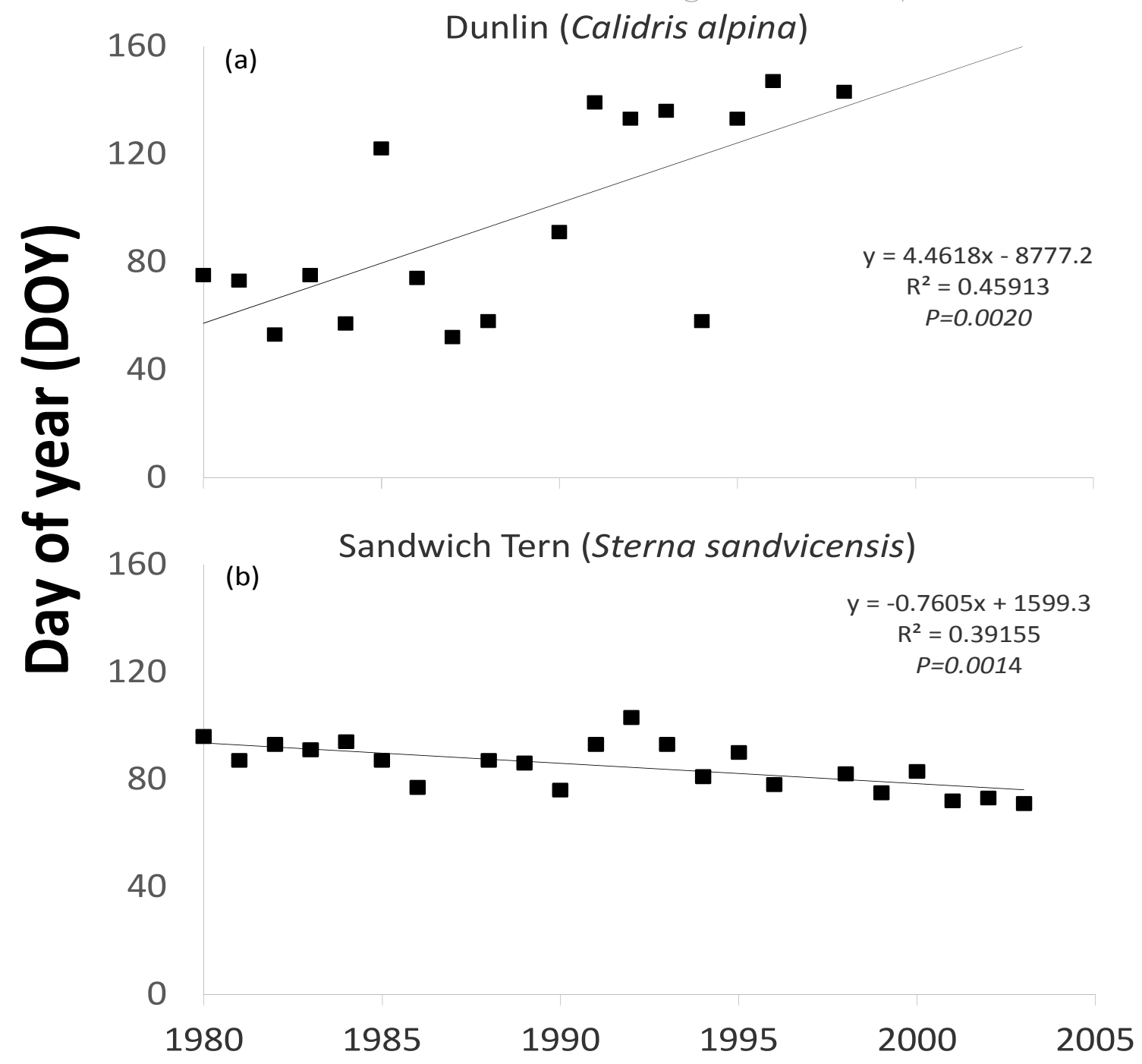


Figure 4 (on next page)

Figure 4

Trend in the timing of departure (latest spring record) of Northern Pintail to the east coast of Ireland over the time period 1980-2003 in relation to average spring (February-April) temperature. 


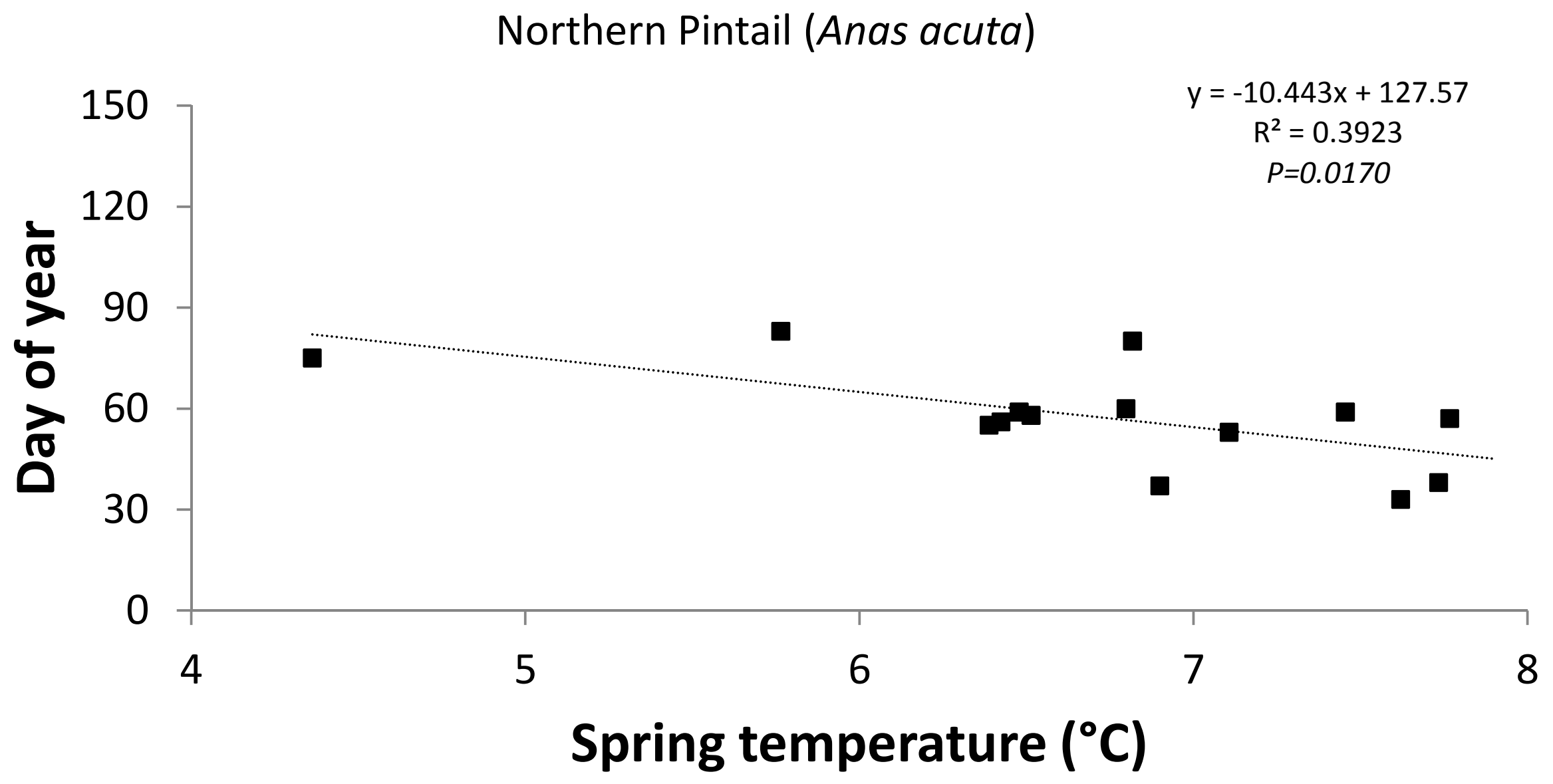


Figure $\mathbf{5}$ (on next page)

Figure 5

Trend in the timing of the latest spring record of Red-throated Diver in the east coast region of Ireland over the time period 1980-2003 in relation to the North Atlantic Oscillation - winter index. 


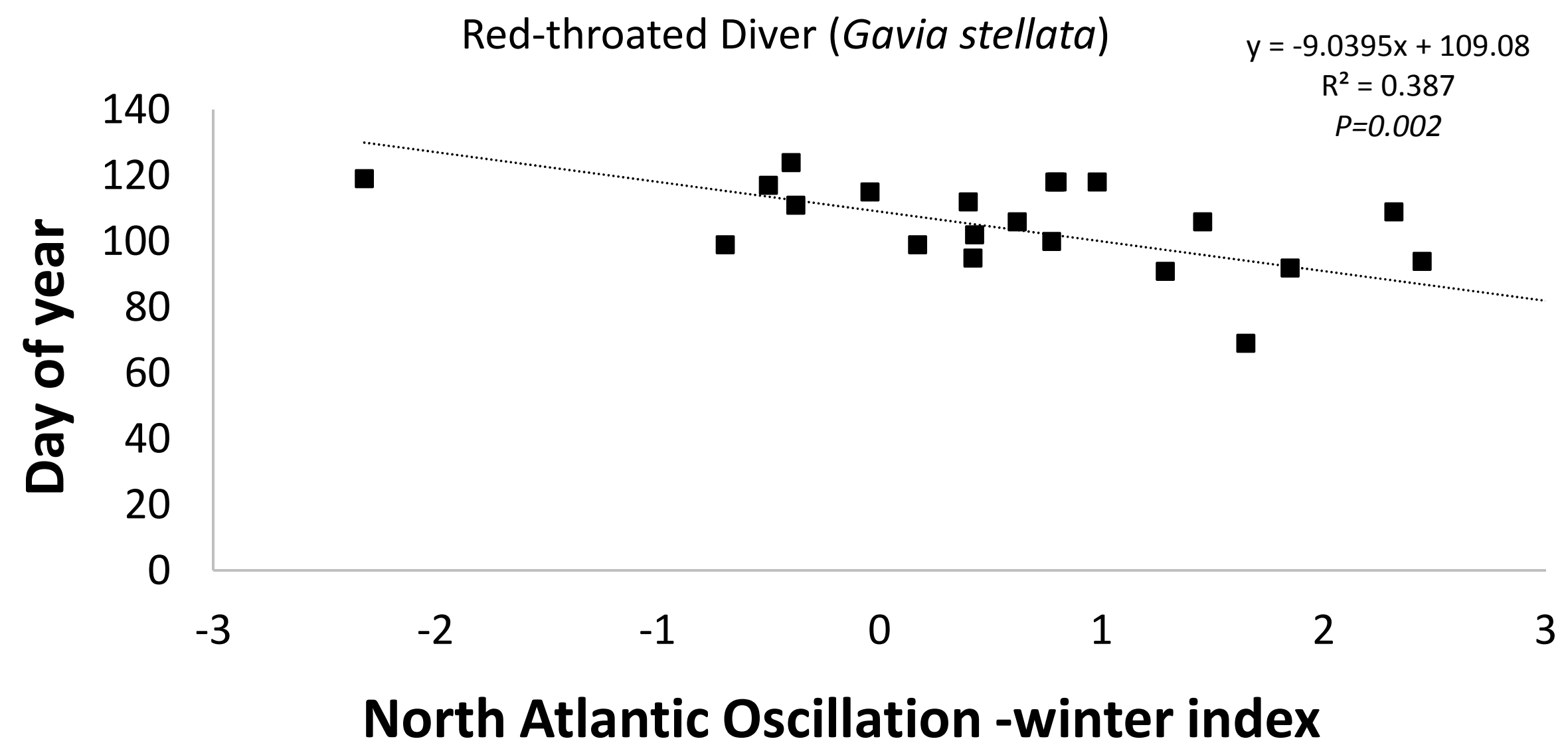

